\title{
Analysis of electric vehicle charging using the traditional generation expansion planning analysis tool WASP-IV
}

\author{
Aoife FOLEY (ه), Brian Ó GALLACHÓIR
}

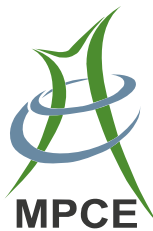

\begin{abstract}
Electric vehicles (EV) are proposed as a measure to reduce greenhouse gas emissions in transport and support increased wind power penetration across modern power systems. Optimal benefits can only be achieved, if EVs are deployed effectively, so that the exhaust emissions are not substituted by additional emissions in the electricity sector, which can be implemented using Smart Grid controls. This research presents the results of an EV roll-out in the all island grid (AIG) in Ireland using the long term generation expansion planning model called the Wien Automatic System Planning IV (WASP-IV) tool to measure carbon dioxide emissions and changes in total energy. The model incorporates all generators and operational requirements while meeting environmental emissions, fuel availability and generator operational and maintenance constraints to optimize economic dispatch and unit commitment power dispatch. In the study three distinct scenarios are investigated base case, peak and off-peak charging to simulate the impacts of EV's in the AIG up to 2025.
\end{abstract}

Keywords Economic dispatch, Environmental dispatch, Plug-in electric vehicle, Generation expansion planning, Carbon dioxide emissions, Energy

CrossCheck date: 27 February 2015

Received: 19 November 2014 / Accepted: 16 April 2015/Published online: 13 May 2015

(C) The Author(s) 2015. This article is published with open access at Springerlink.com

A. FOLEY, School of Mechanical and Aerospace Engineering,

Queen's University Belfast, Belfast BT9 5AH, UK

( $)$ e-mail: a.foley@qub.ac.uk

B. Ó GALLACHÓIR, School of Engineering, University

College Cork, College Road, Cork, Ireland

B. Ó GALLACHÓIR

e-mail: b.ogallachoir@ucc.ie

\section{Introduction}

Internationally the drive is on to deploy electric vehicles (EV), especially as the new mode of private vehicular transport in urban areas. As society is concentrated at urban and suburban centers with average weekly travel distances of approximately 50 miles or 80 kilometers and daily commutes of up to 20 miles or 32 kilometers, this is an opportunity to apply a technology with certain limitations and constraints $[1,2]$. There are a number of economic and environmental benefits to introducing EVs, including reduced oil consumption and dependency, new research and development and associated job opportunities, a reduction in greenhouse gas (GHG) emissions, a reduction in localized noise levels and a reduction in localized air pollution from other pollutants such as particulate matter $\left(\mathrm{PM}_{10}\right)$. These pollutants are linked to global warming, localized air pollution and deterioration in the quality of human health. The International Energy Agency (IEA) studied the effects of a strong policy of 'decarbonisation' in transport and estimated that the introduction of new vehicle technologies and fuels including some modal shifting in passenger and freight transport has the potential to generate a $40 \%$ reduction in carbon $\left(\mathrm{CO}_{2}\right)$ emissions [3].

Many articles study potential GHG emissions reductions from EVs. Boschert [4] provides a detailed review of over 40 studies carried out in the USA to examine the effects of EVs on well-to-wheel emissions [4]. In [5], future trends of both direct and life cycle energy demand and GHG emissions in China's road transport sector are examined, and the effectiveness of possible reduction measures by using alternative vehicles/fuels is assessed and plug-in hybrid electric vehicles were found effective at reducing GHG emissions. In [6], two planning issues are simultaneously examined by employing a multi-objective collaborative planning method (MCPM). It is shown that MCPM can largely improve 
investment efficiency and the user equilibrium based traffic assignment model (UETAM) is seamlessly integrated to address the maximal traffic flow capturing problem successfully. In [7], a framework for optimal design of battery charging/swap stations in distribution systems (i.e. IEEE 15-bus and IEEE 43-bus) based on life cycle cost is provided and the results show that battery swap stations are more appropriate for public transport in distribution systems. As detailed by [8], many different methods are being used to examine EV battery charging.

In this paper a model of the all island grid (AIG) of the Republic of Ireland and Northern Ireland up to 2025 was built employing the dynamic programming (DP) based capacity generation expansion planning tool called Wien Automatic System Planning IV (WASP-IV) created by the International Atomic Energy Agency (IAEA) [9] to determine the potential contribution that plug-in hybrid electric vehicle (PHEV) charging can make in reducing $\mathrm{CO}_{2}$ emissions and changes total energy. In a comparable study of the AIG the impact of PHEV charging is also investigated in 2020, but using an economic dispatch unit commitment model and one of the key findings demonstrated that indicated that peak charging has more negative power system impacts than off-peak charging (i.e. the night-time valley) [10]. In a further follow-up study by [11] of the AIG in 2025 it was shown that gas will be the dominant source of electricity generation to charge EVs and that wind power will experience a minor reduction in curtailment. This paper is divided into six sections. Section 1 introduces and Sect. 2 provides an overview of $\mathrm{EV}$ policy and original equipment manufacturers (OEM) targets. Section 3 describes the DP based capacity generation expansion planning tool, WASPIV. Section 4 sets-out the methodology used, Sect. 5 presents the results and analysis of the baseline, peak and offpeak scenarios and Sect. 6 summaries and concludes.

\section{Overview electric vehicle policy and original equipment manufacturer development targets}

Table 1 presents some international targets [12, 13]. European policies on EVs are provided by AVERE (2010) [14].

A number of countries including some EU Member States, Japan, South Korea, Canada, China, Israel and the USA have established EV targets, policies and plans. For example in the EU each Member State is mandated to ensure that $10 \%$ of transport energy (excluding aviation and marine transport) comes from renewable sources by 2020 [15]. The Irish Government intends to achieve this target with a number of policies including an increase in the use of $3 \%$ biofuels in transport by 2010 and ensuring that $10 \%$ of all vehicles in the transport fleet are powered by electricity
Table 1 Some international EV target objectives

\begin{tabular}{|c|c|}
\hline Country & Targets \\
\hline Austria & 2020: 100000 EVs deployed ${ }^{\mathrm{a}}$ \\
\hline Australia & $\begin{array}{l}\text { 2012: First cars on road, 2018: mass deployment, } \\
\text { 2050: up to } 65 \% \text { of car stock }{ }^{\mathrm{b}}\end{array}$ \\
\hline Canada & 2018: 500000 EVs deployed ${ }^{\mathrm{c}}$ \\
\hline China & 2011: 500000 annual production of EVs ${ }^{\mathrm{d}}$ \\
\hline Denmark & 2020: $200000 \mathrm{EVs}^{\mathrm{e}}$ \\
\hline France & 2020: $2000000 \mathrm{EVs}^{\mathrm{f}}$ \\
\hline Germany & 2020: 1000000 EVs deployed $^{\mathrm{g}}$ \\
\hline Ireland & 2020: $10 \%$ EV market share ${ }^{\mathrm{h}}$ \\
\hline Israel & $\begin{array}{l}\text { 2011: } 40000 \mathrm{EVs}, 2012: 40000 \text { to } 100000 \mathrm{EVs} \\
\text { annually }{ }^{\mathrm{i}}\end{array}$ \\
\hline Japan & 2020: $50 \%$ market share of next generation vehicles ${ }^{\mathrm{j}}$ \\
\hline $\begin{array}{l}\text { New } \\
\text { Zealand }\end{array}$ & 2020: $5 \%$ market share, 2040: $60 \%$ market share ${ }^{\mathrm{k}}$ \\
\hline Spain & 2014: 1000000 EVs deployed ${ }^{1}$ \\
\hline Sweden & 2020: 600000 EVs deployed ${ }^{\mathrm{m}}$ \\
\hline $\begin{array}{l}\text { United } \\
\text { Kingdom }\end{array}$ & No target figures, but policy to support EVs ${ }^{\mathrm{n}}$ \\
\hline USA & 2015: 1000000 PHEV stock $^{\circ}$ \\
\hline
\end{tabular}

a http://www.iea-retd.org/

${ }^{\mathrm{b}}$ http://australia.betterplace.com/assets/pdf/Better_Place_Australia

c http://www.evtrm.gc.ca/pdfs/E-design_09_0581_electric_vehicle

${ }^{\mathrm{d}}$ http://www.nytimes.com/2009/04/02/business/global/02electric. html

e http://www.ens.dk/en-US/Sider/forside.aspx

${ }^{f}$ http://www.physorg.com/news 173639548.html

g http://www.evworld.com/news.cfm?newsid=23301

${ }^{\mathrm{h}}$ http://www.dcenr.gov.ie/Press+Releases/2008/

${ }^{\mathrm{i}} \mathrm{http} / / / \mathrm{www} \cdot$ betterplace.com/

j http://www.autosavant.com/2008/08/27/japan-charges-ahead-withelectric-cars/

${ }^{k}$ http://www.msnbc.msn.com/id/21246592/

${ }^{1}$ http://uk.reuters.com/article/idUKARO04096020080730

${ }^{\mathrm{m}}$ http://www.powercircle.org/en/display/Projects/swedish-electricmobility-initative.aspx

${ }^{\mathrm{n}}$ http://www.dft.gov.uk/pgr/scienceresearch/technology/ lowcarbonelecvehicles/

${ }^{\circ}$ http://www.businessweek.com/technology/content/jun2010/ tc2010063_322564.htm

by 2020 [16]. In addition to the benefits of EVs already discussed there is also the potential opportunity to use EVs to better integrate renewable energy sources (RES). The development of EVs involves two sectors, the battery manufacturers and the EV manufacturers.

Table 2 presents the latest data available with regard to a number of OEM in terms of a technology roadmap [12, 17]. Bayerische Motoren Werke AG (BMW) announced in early June 2010 that it was ceasing further work on the electric mini as it was too expensive to build. BMW's 
Table 2 OEM technology roadmap

\begin{tabular}{lll}
\hline Car manufacturer & Battery manufacturer & Production target \\
\hline BYD Auto & BYD Group & $2015: 100000^{\mathrm{a}}$ \\
Fiat-Chrysler & A123 Systems & No date, no numbers \\
Ford & Johnston Controls-Saft & 5000 per annum \\
GM & LG Chem & $2011: 10000 \& 2012: 60000^{\mathrm{c}}$ \\
Hyundai & LG Chem, SK Energy and SB Limotive & $2018: 500000$ \\
Mercedes-Benz & Continental \& Johnston Controls-Saft & No date, no numbers \\
Mitsubishi & GS Yuasa Corp. & $2010: 5000,2011: 15000$ \\
Nissan & AESC & $2010: 50000,2012: 100000$ \\
REVA & Indocel Technologies & No date, no numbers \\
Renault & AESC & By 2010 150000/annum \\
Subaru & AESC & $2010: 100^{\mathrm{e}}$ \\
Tata & Electrovaya & No date, no numbers \\
Toyota & Panasonic & No date, no numbers \\
Volkswagen & Volkswagen \& Toshiba Corp. & $2011: 500^{\mathrm{f}}$ \\
\hline
\end{tabular}

${ }^{a}$ http://blogs.edmunds.com/greencaradvisor/2010/03/byd

b http://www.autoblog.com/2010/03/22/chrysler

c http://www.greencarreports.com/blog/

${ }^{d}$ http://green.autoblog.com/2009/09/10/officially-official-mercedes-benz

e http://green.autoblog.com/2007/12/26/subaru-ev

${ }^{\mathrm{f}} \mathrm{http} / / /$ green.autoblog.com/2010/03/01/volkswagen

preference is for a battery swopping programme so drivers are not inconvenience at charging points [18].

\section{Generation expansion planning model development in WASP IV}

The methodology employed is traditional long term generation expansion planning (GEP) [19] using WASP-IV the IAEA's commonly used for electricity planning in monopoly electricity markets [20]. In a monopoly market the primary objective of a utility is to meet electricity demand within a 'reasonable' loss of load probability (LOLP) or energy not served (energy not served (ENS) or expected unserved energy is the expected amount of energy not delivered each year because of scarcities in generating capacities and or shortage in energy supplies) at a minimum cost, whereas in a liberalized electricity market the aim is to meet demand at a reduced ENS and wholesale electricity price [21]. However, all things being equal supply should always meet demand at the least cost. The generation expansion model for the AIG is built in WASPIV, which uses three main optimization techniques to find the most optimal portfolio mix for a power system within user defined constraints. Probabilistic estimation is applied to determine system production costs, ENS costs and reliability. Linear programming finds the optimal portfolio mix, which satisfies exogenous constraints on environmental emissions, fuel availability and electricity generation by some plants. The alternative expansion plans are optimized using DP.

WASP-IV is coded in FORTRAN and consists of seven modular programmes with a windows based graphics user interface to input and manipulate data, as shown in Fig. 1.

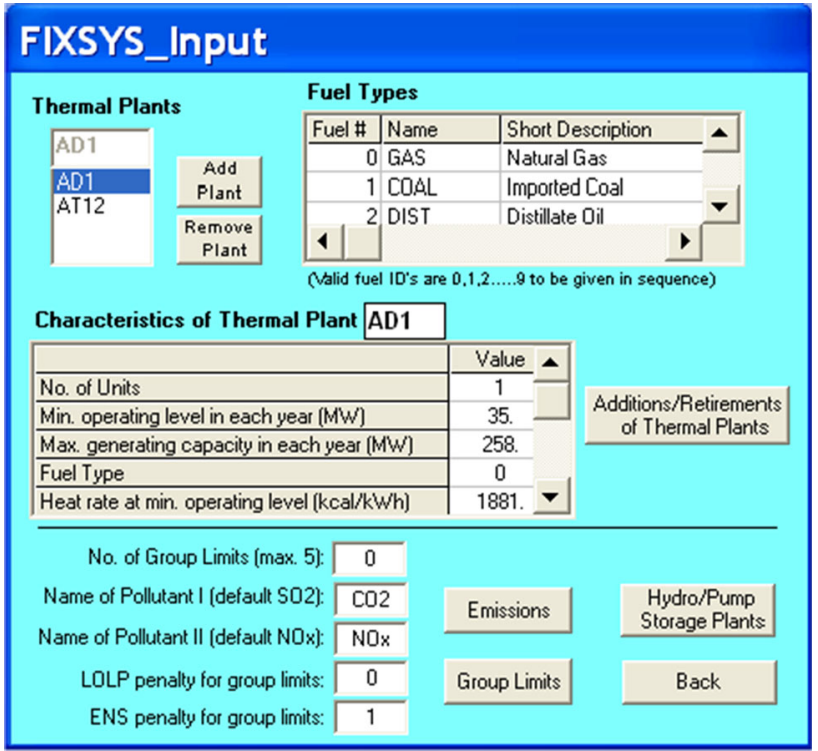

Fig. 1 FIXSYS input screen in WASP-IV 
The seven modular programmes are:

1) Load system (LOADSY), which predicts peak loads and load duration curves (LDC) for the system;

2) Fixed system (FIXSYSY), which describes the existing plant, all future firm additions and all firm retirements;

3) Variable system (VARSYS), which details the candidate plants available to expand the portfolio mix;

4) Configuration generator (CONGEN), produces all possible year to year alternative combinations of expansion configurations;

5) Merge and simulate (MERSIM), merges the system and calculates the production costs, ENS and system reliability denoted by LOLP for each configuration;

6) Dynamic programming optimization (DYNPRO), establishes the optimal expansion plan based on the input data;

7) Report writer of WASP-IV in a batched environment (REPROBAT), summarizes the input data, results of the study and cash flow requirements of the optimal expansion plan.

WASP-IV can determine the optimal GEP for a power system over a period of 30 years, within the system planning constraints, based on total minimum discounted system costs [22]. Each potential series of generators added to the power system, which meets the power system constraints are weighted using a present value cost function. The cost (objective) function is based on (1).

$B_{j}=\sum_{t=1}^{T}\left[\bar{I}_{j, t}-\bar{S}_{j, t}+\bar{L}_{j, t}+\bar{F}_{j, t}+\bar{M}_{j, t}+\bar{O}_{j, t}\right]$

where $B_{j}$ is the objective function of the expansion plan $j ; \boldsymbol{I}_{j}$ are the capital investment costs of expansion plan $j ; S_{j}$ are the salvage value of investment costs of the expansion plan $j ; \boldsymbol{F}_{j}$ are the fuel costs of expansion plan $j ; \boldsymbol{L}_{j}$ are the fuel inventory costs of the expansion plan $j ; \boldsymbol{M}_{j}$ are the non-fuel operation and maintenance costs of the expansion plan $j ; O_{j}$ is the cost of ENS of the expansion plan $j$; during the time, $t$ in years 1 , $2, \ldots, T$, where $T$ is the planning period. The horizontal bar represents discounted values to a reference year or base year at a given discount $i$. The optimal expansion plan is defined by minimizing $B_{j}$ to all $j$. As WASP-IV uses DP the analysis based on Bellman's Principle of Optimality requires a start point to determine the all the possible alternative expansion plans in power system [23]. If $\boldsymbol{K}_{t}$ is a vector containing all the generating units in operation in year $t$ for a given expansion plan, then $\boldsymbol{K}_{t}$ must satisfy (2).

$\boldsymbol{K}_{t}=\boldsymbol{K}_{t-1}+\boldsymbol{A}_{t}-\boldsymbol{R}_{t}+\boldsymbol{U}_{t}$

where $\boldsymbol{A}_{t}$ equals a vector of committed additions of units in year $t ; \boldsymbol{R}_{t}$ equals a vector of committed retirements of units in year $t$ and $\boldsymbol{U}_{t}$ equals a vector of candidate units added to the system in year $t$. The installed capacity must lie between the maximum and minimum reserve margins, above the peak demand $D_{t, p}$ in the critical period, $p$ of the year and is defined by the following constraint set-out in (3).

$$
\left(1+a_{t}\right) D_{t, p} \geq P\left(K_{t, p}\right) \geq\left(1+b_{t}\right) D_{t, p}
$$

In WASP-IV the system reliability is configured using LOLP. The LOLP index is calculated for each period of the year and each hydro-condition in the same period weighted by the hydro-condition probabilities and the average annual LOLP. The generation of each plant during each period is determined using the optimal dispatch policy in WASP-IV, which is based on the availability of plants and units, maintenance of plants and units, spinning reserve (spinning reserve (SR) is the unused capacity which can be activated on decision of the system operator and which is provided by devices which are synchronized to the network and able to affect the active power) [24] requirements and other exogenous constraints such as environmental emissions, fuel usage and or availability of certain plants as described in (4).

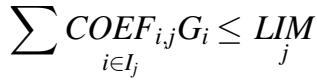

where $G_{i}$ is the generation by plant $I ; C O E F_{i, j}$ is per unit emission or per unit fuel usage and so forth by $i$ plant in the group limited by $j$.

\section{Methodology}

\subsection{Test system}

The test system modelled is the AIG in 2010, which had an existing installed 'dispatchable' capacity of $9742 \mathrm{MW}$, approximately $5842 \mathrm{MW}$ of which was gas fired. There was an installed wind power capacity of circa 1533 MW. There is a $275 \mathrm{kV}$ double circuit interconnector and two standby $110 \mathrm{kV}$ lines between Northern Ireland and the Republic of Ireland. The AIG is linked to the Great Britain grid via the Moyle $500 \mathrm{MW}$ high voltage direct current (HVDC) interconnector and the 500 MW HVDC East West interconnector. Thus the AIG can be treated as one synchronous system. The baseline model data was collected from information published by the single wholesale electricity market operator (SEMO), the transmission system operators (TSO) and the regulators for Northern Ireland and in the Republic of Ireland and all island market modelling project and the AIG study [25-31]. This is the base case scenario. 


\subsection{Scenario approach}

For each year up to 2025 two distinct charging scenarios are applied to the base case scenario peak charging when PHEV charge during the pm peak (i.e. starting $5.30 \mathrm{pm}$ ) and off-peak charging (between $10 \mathrm{pm}$ and $6 \mathrm{am}$ ) in order to simulate the effect of PHEV on the power system. The peak time window is assigned assuming that this is the time when PHEV owners arrive home from work. This is a practical assumption because the deployment of smart metering and Smart Grid has not been as rapid as anticipated [32]. The off-peak times are chosen as this is the power system nighttime valley with spare capacity. Figure 2 shows the flowchart approach used to examine the impacts of the two PHEV load profiles on the power system.

The number of PHEVs charging per annum is estimated using the results of the 'Car Stock' model [33]. Figure 3 provides a graph of the growth in PHEVs of the passenger car fleet in the Republic of Ireland only, from 2010 to 2025 inclusive as estimated by 'Car Stock'. For the purpose of this model a $10 \%$ (i.e. 262068) PHEV target is achieved in 2020.

As the alternating current (AC) from the grid is converted to direct current (DC) in the EV battery pack there will be power losses associated with stationary loads in the

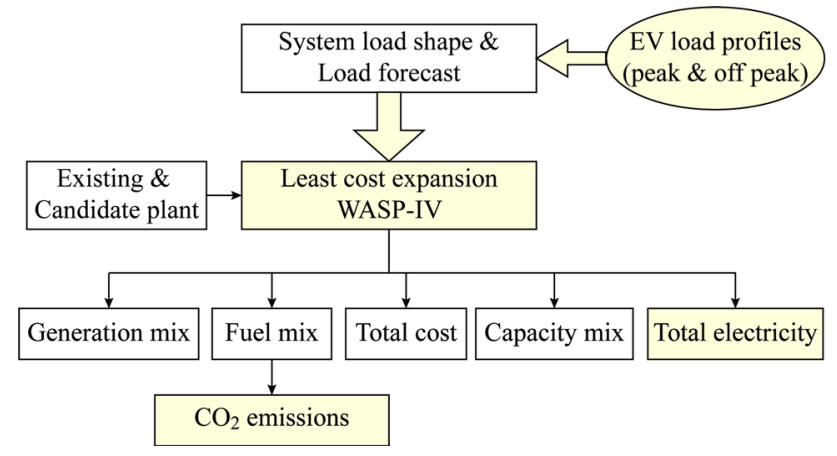

Fig. 2 WASP-IV GEP \& $\mathrm{CO}_{2}$ flowchart

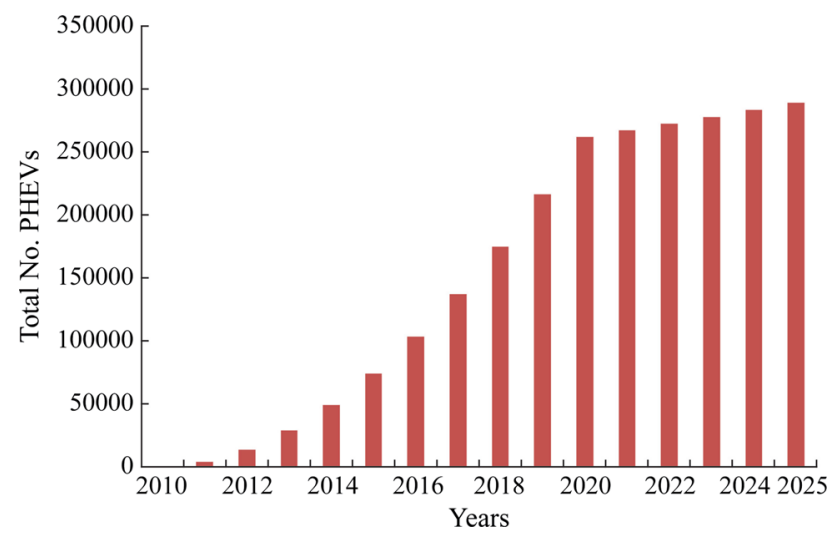

Fig. 3 PHEV numbers from 2010 to 2025 charging process e.g. communication controls and the battery/engine cooling system [34]. It is assumed $88 \%$ conversion efficiency from AC to DC [35]. Thus more power is actually required to full charge the PHEV. For this study it is assumed that charging will take place mostly at the PHEV home at level 1 charging using a $3.3 \mathrm{~kW}$ charger, which includes the conversion efficiency factor over 8 hours with 'trickle' charging of the battery to reach a full state of charge (SOC). This applies the same methodology used in the 'EV Car Stock' model, where plug-to-battery energy losses of $88 \%$ conversion efficiency were used [36]. In order to determine the additional energy used and the amount of $\mathrm{CO}_{2}$ produced by the power system, WASP-IV is ran without the load of the PHEV (i.e. base case) and with the load of the PHEV for both the peak and off-peak charging regimes.

In the test system power dispatch is optimized using hourly electricity demand curves over an entire year (i.e. 8760 hours) for each year up to 2025 . The baseline year is 2009. Figure 4 shows the load duration curve for 2009. A conservative growth of $1.15 \%$ per annum in electricity demand is taken up to 2025. This data was inputted into WASP-IV using PRELOAD2.

Peak charging is assumed to occur during peak electricity usage, which is typically between $12 \mathrm{pm}$ and $10 \mathrm{pm}$ each day. Off-peak charging is assumed to occur during the period of lowest electricity demand, typically between 10 pm and 6 am. As already discussed a trickle charge approach was applied over the 8 hours. In trickle charging the battery draws load quickly for the first 3 hours typically and then slowly thereafter, as in a 'trickle'.

Wind power generation in this study is established in WASP-IV as a 'fictitous' run-of-hydro unit. The installed wind power capacity for each year was linearly extrapolated starting with $1533 \mathrm{MW}$ of installed wind capacity in 2009 and $6000 \mathrm{MW}$ in 2020. The Republic of Ireland has a target of generating $40 \%$ electricity from RES, which is expected to come predominantly from wind power by 2020 [37]. Northern Ireland currently has a re-

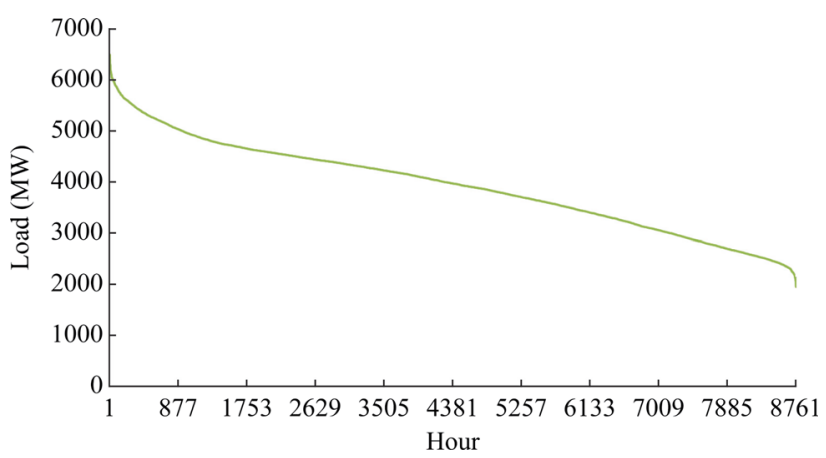

Fig. 4 Load duration curve for base year 
Table 3 Dispatchable plant in AIG

\begin{tabular}{|c|c|c|c|}
\hline Plant & $\begin{array}{l}\text { ID } \times \text { no } \\
\text { units }\end{array}$ & $\begin{array}{l}\text { Net capacity } \\
\text { (MW) }\end{array}$ & Fuel type \\
\hline Aghada & $\mathrm{AD} \times 1$ & 258 & Gas \\
\hline Aghada & $\mathrm{AT} \times 3$ & 90 & Gas \\
\hline Aghada & $\mathrm{ADC} \times 1$ & 432 & Gas \\
\hline Ballylumford ST & $\mathrm{B} 1 \times 3$ & 170 & Gas \\
\hline Ballylumford CCGT & B $2 \times 3$ & 170 & Gas \\
\hline Ballylumford GT & B3 $\times 2$ & 58 & Gas \\
\hline Ballylumford CCGT & $\mathrm{B} 10 \times 1$ & 97 & Gas \\
\hline Cahir OCGT & $\mathrm{CH} 1 \times 1$ & 98 & Gas \\
\hline Cuilleann OCGT & CL1 $1 \times 1$ & 98 & Gas \\
\hline Coolkeragh & $\mathrm{CO} 1 \times 1$ & 53 & Oil \\
\hline Coolkeragh CCGT & $\mathrm{CO} 2 \times 1$ & 402 & Gas \\
\hline Dublin Bay & $\mathrm{DB} 1 \times 1$ & 403 & Gas \\
\hline Dublin Waste Energy & DW $1 \times 1$ & 72 & Waste \\
\hline East West Interconnector & EWIC & 500 & - \\
\hline Edenderry & $\mathrm{ED} 1 \times 1$ & 117.6 & Peat \\
\hline Edenderry OCGT & $\mathrm{ED} 2 \times 1$ & 111 & Gas \\
\hline Great Island & GIA $\times 2$ & 54 & Gas \\
\hline Great Island & $\mathrm{GIB} \times 1$ & 108 & Gas \\
\hline Huntstown & $\mathrm{HNI} \times 1$ & 343 & Gas \\
\hline Huntstown & $\mathrm{HN} 2 \times 1$ & 401 & Gas \\
\hline Kilroot & $\mathrm{KC} \times 2$ & 29 & Oil \\
\hline Kilroot & $\mathrm{KO} 1 \times 2$ & 40 & Oil \\
\hline Kilroot & $\mathrm{KO} 2 \times 1$ & 400 & Gas \\
\hline Lough Ree Power & $\mathrm{LR} 4 \times 1$ & 91 & Peat \\
\hline Marina & MRT $\times 1$ & 85 & Gas \\
\hline Meath waste to energy & $\mathrm{MW} \times 1$ & 17 & Waste \\
\hline Moyle interconnector & $\mathrm{MI} \times 1$ & 450 & - \\
\hline Moneypoint & $\mathrm{MP} \times 3$ & 282.5 & Coal \\
\hline Nore Power & $\mathrm{NP} \times 1$ & 98 & Gas \\
\hline North Wall & NW1 $1 \times 1$ & 163 & Oil \\
\hline North Wall & NW $2 \times 1$ & 104 & Gas \\
\hline Poolbeg & $\mathrm{PBC} \times 1$ & 463 & Gas \\
\hline Rhode Island & $\mathrm{RP} 1 \times 2$ & 52 & Gas \\
\hline Sealrock & $\mathrm{SK} \times 2$ & 80.5 & Gas \\
\hline Tarbert & $\mathrm{TB} 1 \times 2$ & 54 & Oil \\
\hline Tarbert & $\mathrm{TB} 3 \times 2$ & 241 & Oil \\
\hline Tawnaghmore & $\mathrm{TP} \times 2$ & 52 & Gas \\
\hline Tynagh & $\mathrm{TY} \times 1$ & 384 & Gas \\
\hline West Offaly & WO $\times 1$ & 137 & Gas \\
\hline Whitegate & $\mathrm{WG} \times 1$ & 445 & Gas \\
\hline Ardnacrusha Hydro & $\mathrm{AA} \times 4$ & 21.5 & Water \\
\hline Erne Hydro & $\mathrm{ER} \times 4$ & 16.25 & Water \\
\hline Lee Hydro & $\mathrm{LE} \times 4$ & 9 & Water \\
\hline Liffey Hydro & $\mathrm{LI} \times 4$ & 9.5 & Water \\
\hline Turlough Hill & $\mathrm{TH} \times 4$ & 73 & Water \\
\hline
\end{tabular}

Table 4 Fuel costs

\begin{tabular}{ll}
\hline Fuel type & Cost $(€ / \mathrm{GJ})$ \\
\hline Gas OCGT & 5.91 \\
Gas CCGT & 6.46 \\
Coal & 1.75 \\
Peat & 3.71 \\
Wind & 2.78 \\
Hydro & 0 \\
\hline
\end{tabular}

newable target of $12 \%$ electricity production from indigenous sources by 2012. In 2010 a revised target of $42 \%$ power from RES, mostly from off-shore wind power, by 2020 was under consultation. The Northern Ireland Assembly subsequently agreed an increased renewable target of $40 \%$ electricity production from indigenous sources by $2020[38,39]$. All the dispatchable plants inputted into WASP-IV are listed in Table 3.

The fuel prices used in the study are given in Table 4 are the average of the prices published in the AIG study [40].

Finally, note that the SR was left at the default value of $10 \%$ in WASP-IV for the test system simulations.

\section{Results and analysis}

Figure 5 shows the graph of total energy with and without PHEV charging from 2010 to 2025 . Both peak and off-peak charging modes use in effect approximately the same amount of total energy per annum, as expected. As can be seen from the graph the total amount of energy produced increases as would be expected as the number of PHEVs charging increases. PHEV charging accounts for approximately $1184 \mathrm{GWh}$ of additional energy in electricity in 2020. $1073 \mathrm{GWh}$ of additional energy in electricity in 2020 or around 93 kilotonne oil equivalent (ktoe) (A tonne of oil equivalent (toe) is a unit of energy roughly equivalent to the energy content of one tonne of crude oil. The definition in energy terms is that 1 toe $=11.63 \mathrm{Mega}$ Watt hours $\left.(\mathrm{MWh})=1.163 \times 10^{-2} \mathrm{GWh}\right)$, of which $42 \%$ is renewable, which equates to 97.65 ktoe when the 2.5 weighting is applied in accordance with Directive 2009/28/ EC. Therefore PHEVs could contribute $1.68 \%$ to the $10 \%$ renewable energy in transport target in the Republic of Ireland.

Figure 6 shows the graph of total $\mathrm{CO}_{2}$ emitted without PHEV charging, with PHEV off-peak and with PHEV peak charging from 2010 to 2025. As can be seen from the graph the amount of $\mathrm{CO}_{2}$ produced without PHEV charging is the lowest, as would be expected. The amount of $\mathrm{CO}_{2}$ emis- 


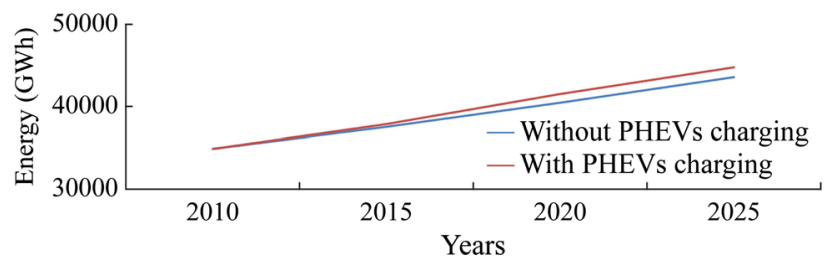

Fig. 5 Total energy with \& without PHEV charging

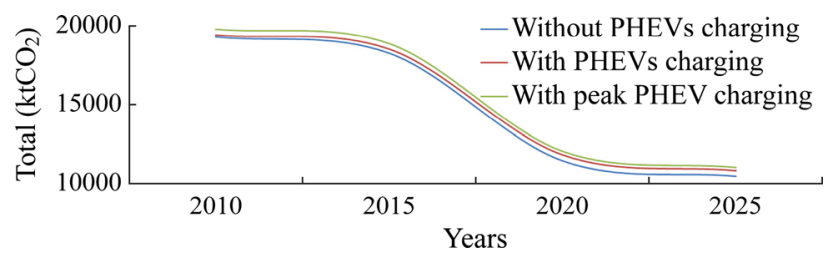

Fig. 6 Total systems $\mathrm{CO}_{2}$ emissions per scenario

sions also decreases year on year due to the increase in installed wind. The PHEV peak charging generates more $\mathrm{CO}_{2}$ emissions than the off-peak charging as less efficient peaking and mid-merit thermal generators are used.

This model has not taken into account the stochastic nature of wind power on the system, which may result in increased $\mathrm{CO}_{2}$ emissions due to cycling and part loading of thermal generators [41] (cycling is the operation of thermal generation units at varying load levels, low load levels or in a start/stop manner and has cost implications for operation and maintenance of thermal plant). The analysis is also limited because the impacts of using surplus wind on the AIG system to charge PHEV was not included.

The difference in $\mathrm{CO}_{2}$ emissions between the baseline case, without PHEVs charging and with PHEVs charging for both the peak and off-peak scenarios is 598 kilotonne of $\mathrm{CO}_{2}\left(\mathrm{ktCO}_{2}\right)$ and $375 \mathrm{ktCO}_{2}$, respectively in 2020. If the Car Stock model $\mathrm{CO}_{2}$ savings in ICE reductions of 504 $\mathrm{ktCO}_{2}$ is included, then the overall net reduction in $\mathrm{CO}_{2}$ emissions is a reduction of $129 \mathrm{ktCO}_{2}$ for the off-peak scenario but an increase of $94 \mathrm{ktCO}_{2}$ for the peak scenario. Thus WASP-IV indicates that peak charging increases $\mathrm{CO}_{2}$ emissions. Therefore off-peak charging has more overall transport and power systems benefits in terms of $\mathrm{CO}_{2}$ emissions reductions and contributes $0.95 \%$ to the Republic of Ireland's 20\% reduction in non-emissions trading scheme emissions by 2020 relative to 2005 [42].

\section{Conclusion}

This paper has presented the results of an examination of the impacts of PHEVs charging on the AIG using the WASP-IV long term GEP model and two charging scenarios. The analysis indicates that off-peak charging during the night-time valley is the most efficient with the lowest increase in $\mathrm{CO}_{2}$ emissions. This is because base load plants are used. It was found that PHEV charging accounts for approximately $1184 \mathrm{GWh}$ of additional energy in electricity in 2020. $1073 \mathrm{GWh}$ of additional energy in electricity in 2020 or around $93 \mathrm{ktoe}$, of which $42 \%$ is renewable, which equates to 97.65 ktoe when the 2.5 weighting is applied in accordance with Directive 2009/28/ EC. The difference in $\mathrm{CO}_{2}$ emissions between the baseline case, without PHEVs charging and with PHEVs charging for both the peak and off-peak scenarios is $598 \mathrm{ktCO}_{2}$ and $375 \mathrm{ktCO}_{2}$, respectively in 2020 . The model revealed that PHEVs have the potential to contribute $1.68 \%$ to the $10 \%$ renewable energy in transport target in the Republic of Ireland. The model also shows that off-peak PHEV charging has more overall transport and power systems benefits in terms of $\mathrm{CO}_{2}$ emissions reductions and contributes $0.95 \%$ to the Republic of Ireland's 20\% reduction in non-emissions trading scheme emissions by 2020 relative to 2005. The next phase of this research is to develop a wind-follow Smart Grid charging scenario.

Acknowledgments Dr Aoife FOLEY would like to thank UK Engineering and Physical Sciences Research Council (EPSRC) under grant EP/L001063/1 and the National Natural Science Foundation of China under grants 51361130153 and 61273040 and the Shanghai Rising Star programme 12QA1401100 for financial supporting this research. Dr Aoife FOLEY and Dr Brian Ó GALLACHÓIR would also like to thank the Irish Environmental Protection Agency (EPA) Climate Change Research Programme under grant CCRP-09-FS-7-2. Dr FOLEY also acknowledges Dr Jianhui WANG, Vladimir KORITAROV, Dr Aidun BOTTERUD, Guenter CONZELMANN at Argonne National Energy Laboratory, Illinois, USA.

Open Access This article is distributed under the terms of the Creative Commons Attribution 4.0 International License (http:// creativecommons.org/licenses/by/4.0/), which permits unrestricted use, distribution, and reproduction in any medium, provided you give appropriate credit to the original author(s) and the source, provide a link to the Creative Commons license, and indicate if changes were made.

\section{References}

[1] Morgenroth ELW (2002) Commuting in Ireland: an analysis of inter-county commuting flows. WP 144, Economic and Social Research Institute (ESRI), Dublin

[2] National Travel Survey (2012) Statistical release. Department for Transport, London, 2013

[3] International Energy Agency (IEA) (2009) Transport, energy and $\mathrm{CO}_{2}$ : moving towards sustainability. IEA/Organisation for Economic Co-operation and Development (OECD), Paris

[4] Boschert S (2008) The cleanest cars: well-to-wheels emissions comparisons. New Society Publishers, Gabriola Island

[5] Ou XM, Zhang XL, Chang SY (2010) Scenario analysis on alternative fuel/vehicle for China's future road transport: lifecycle energy demand and GHG emissions. Energy Policy 38(8):3943-3956 
[6] Yao WF, Zhao JH, Wen FS et al (2014) A multi-objective collaborative planning strategy for integrated power distribution and electric vehicle charging systems. IEEE Trans Power Syst 29(4):1811-1821

[7] Zheng Y, Dong ZY, Xu Y et al (2014) Electric vehicle battery charging/swap stations in distribution systems: comparison study and optimal planning. IEEE Trans Power Syst 29(1):221-229

[8] Zhang C, Li K, McLoone S et al (2014) Battery modelling methods for electric vehicles-a review. In: Proceedings of the 2014 European control conference (ECC'14) Strasbourg, 24-27 June 2014

[9] Wien Automatic System Planning (WASP-IV), Version 4. International Atomic Energy Agency (IAEA), Vienna

[10] Foley A, Tyther B, Calnan P et al (2013) Impacts of electric vehicle charging under electricity market operations. Appl Energy 101:93-102

[11] Calnan P, Deane JP, Ó Gallachóir BP (2013) Modelling the impact of EVs on electricity generation, costs and $\mathrm{CO}_{2}$ emissions: assessing the impact of different charging regimes and future generation profiles for Ireland in 2025. Energy Policy 61:230-237

[12] International Energy Agency (IEA) (2009) Technology roadmap: electric and plug-in hybrid electric vehicles. IEA/Organisation for Economic Co-operation and Development (OECD), Paris

[13] Investigation into the scope for the transport sector to switch to electric vehicles and plug-in hybrid vehicles. Department for Business, Enterprise and Regulatory Reform, Department for Transport, London, 2008

[14] AVERE: The European Association for Battery, Hybrid and Fuel Cell Vehicles (2014). http://www.avere.org/www/index.php

[15] The European Parliament and the Council of the European Union (2009) Directive 2009/28/EC of the European parliament and the council of 23 April 2009 on the promotion of the use of energy from renewable sources and amending and subsequently repealing directives 2001/77/EC and 2003/30/EC. Official Journal of the European Union, L 140/16

[16] Minister for Energy (2009) Eamon Ryan and Transport Minister, Noel Dempsey, T.D. Ireland, Sustainability Moves to the Centre of Transport Policy, Press Release, http://nta.gov.ie/pressRelease. aspx? $\mathrm{Id}=45$

[17] Fleet B, Li JK, Gilbert R (2008) Situation analysis for the current state of electric vehicle technology for the natural resources Canada. In: Electric vehicle technology roadmap visioning meeting, Ottawa, 26 June 2008

[18] Byrne D (2010) BMW unplugs the electric mini. The Irish Times, 9 June 2010

[19] Stoll HG (1989) Least-cost electric utility planning. Wiley, New York

[20] Hertzman D (2007) Risk assessment methods for power utility planning. Special Report, Energy Management Assistance Programme of the World Bank, Washington, DC

[21] Foley AM, Ó Gallachóir BP, Hur J et al (2010) A strategic review of electricity systems models. Energy 35(12):4522-4530

[22] Wien automatic system planning (WASP) package (2006) A computer code for power generating system expansion planning, version WASP-IV with user interface, user's manual. International Atomic Energy Agency (IAEA), Vienna

[23] Bellman R (1957) Dynamic programming. Princeton University Press, Princeton

[24] Rebours Y, Kirschen D (2005) What is spinning reserve? Release 1 . The University of Manchester, Manchester

[25] Single Electricity Market Operator (SEMO) (2011) http:// allislandmarket.com
[26] EirGrid, System data (2014). http://www.eirgrid.com/ operations/systemperformancedata

[27] Commission for Energy Regulation (CER) and the Northern Ireland Authority for Utility Regulation (NIAUR) (2013) All Island project. http://www.allislandproject.org

[28] Generation adequacy report 2009-2015. EirGrid. Dublin, 2008

[29] Seven year generation capacity statement 2009-2015. System operator for northern Ireland (SONI) Ltd, Belfast, 2008

[30] All-Island market modelling programme, All island modelling assumptions, model version 0.1. Electricity Supply Board (ESB) National Grid Co, Dublin, 2005

[31] All Island grid study. Department of communications. Marine and Natural Resources and the Department of Enterprise, Trade and Investment, Dublin, 2008

[32] Connor PM, Baker PE, Xenias D et al (2014) Policy and regulation for smart grids in the United Kingdom. Renew Sustain Energy Rev 40:269-286

[33] Daly HE, Ó Gallachóir BP (2011) Modelling private car energy demand using a technological car stock model. Transp Res Part D 16(2):93-101

[34] Evans S (2007) Chargers integral to PHEV success. In: Proceedings of the 23rd international battery, hybrid and fuel cell electric vehicle symposium and expo (EVS'07), vol 4, Anaheim, 2-5 Dec 2007, pp 1942-1947

[35] Duvall M, Knipping E (2007) Environmental assessment of plug-in electric vehicles, Nationwide greenhouse gas emissions. vol 1, Electric Power Research Institute (EPRI), Palo Alto

[36] Foley AM, Daly HE, Ó Gallachóir BP (2010) Quantifying the energy and carbon emissions implications of a $10 \%$ electric vehicles target. In: Proceedings of the 2010 international energy workshop (IEW'10), Stockholm, 21-23 June 2010

[37] Minister for Environment, Heritage and Local Government, John Gormley TD. Press Release, 15 Oct 2008

[38] Strategic energy framework for Northern Ireland (2008) Preconsultation scoping paper. Department of Enterprise, Trade and Investment, London

[39] Draft offshore renewable energy strategic action plan 2009-2020. Department of Enterprise, Trade and Investment, London, 2009

[40] Tuohy A (2009) Operational and policy issues in carbon constrained power systems. PhD Thesis, University College Dublin, Dublin

[41] Denny E, O’Malley M (2007) Quantifying the total net benefits of grid integrated wind. IEEE Trans Power Syst 22(2):605-615

[42] Communication from the Commission to the European Parliament, the Council, the European Economic and Social Committee and the Committee of the Regions, 2020 by 2020 Europe's climate change opportunity. COM (2008) 30 final, Commission of the European Communities, Brussels, 2008

Aoife FOLEY is a Lecturer in the School of Mechanical and Aerospace Engineering, Queen's University Belfast. She has a BE (Hons) (1996), a PhD (2011) from University College Cork and an MSc (Hons) (1999) from Trinity College Dublin. She is a Fellow of Engineers Ireland (2011), a Member of the IEEE PES (2009) and was Secretary of the IEEE VTS UK and Republic of Ireland Chapter (2011). She was awarded an Environmental Protection Agency STRIVE Fellowship (2009) to model the impact of electric vehicles on greenhouse gas emissions. She has more than 12 year's industrial experience. She has authored and co-authored almost 50 peer reviewed technical publications. Her area of research focus is wind power integration using Smart Grids, electricity markets and power systems operations. 
Brian Ó GALLACHÓIR is a Senior Lecturer in Energy Engineering in University College Cork and Principal Investigator of Energy Policy and Modelling Research in UCC's Environmental Research Institute. An applied sciences graduate of Dublin Institute of Technology, Brian moved to Cork in 1990 to carry out a Doctoral research programme in ocean wave energy in the Department of
Applied Mathematics. He co-ordinates the UCC's taught Masters Programme (MEngSc) in Sustainable Energy and co-instigator of UCC's BE Degree in Energy Engineering. His research focus is on energy systems modeling and optimisation. Brian is Chair of the International Energy Agency (IEA)'s Executive Committee on Energy Technology Systems Analysis Programme (ETSAP). 